\title{
Measured ammonia emissions from tropical and subtropical pastures: A comparison with 2006 IPCC, 2019 Refinement to the 2006 IPCC, and EMEP/EEA (European Monitoring and Evaluation Programme and European Environmental Agency) inventory estimates
}

\author{
Claudia Arndt, ${ }^{1,2 *}$ Tom H. Misselbrook, ${ }^{3}$ Andres Vega, ${ }^{1}$ Ricardo Gonzalez-Quintero, ${ }^{4}$ \\ Johan A. Chavarro-Lobo, ${ }^{5}$ Andre M. Mazzetto, ${ }^{6,7}$ and Dave R. Chadwick ${ }^{6}$ \\ ${ }^{1}$ Programa de Agricultura, Ganadería y Agroforestería, Centro Agronómico Tropical de Investigación y Enseñanza, Turrialba, Cartago, 30501, \\ Costa Rica \\ ${ }^{2}$ Grupo de investigación: Cambio climático y ganadería, Facultad de Zootecnia, Universidad Nacional Agraria La Molina, 15025, Peru \\ ${ }^{3}$ Rothamsted Research, North Wyke, Okehampton, Devon, EX20 2SB, United Kingdom \\ ${ }^{4}$ Facultad de Ciencias Agrarias, Universidad de Antioquia, Medellín, 050034, Colombia \\ ${ }^{5}$ Fundación Universitaria Unitropico, Yopal, Casanare, 30501, Colombia \\ ${ }^{6}$ School of Natural Sciences, Bangor University, Bangor, Gwnedd, LL59 5TH, United Kingdom \\ ${ }^{7}$ AgResearch, Lincoln, Canterbury, 7674, New Zealand
}

\section{ABSTRACT}

Agriculture is the largest source of ammonia $\left(\mathrm{NH}_{3}\right)$ emissions. As $\mathrm{NH}_{3}$ is an indirect greenhouse gas, $\mathrm{NH}_{3}$ measurements are crucial to improving greenhouse gas emission inventory estimates. Moreover, $\mathrm{NH}_{3}$ emissions have wider implications for environmental and human health. Only a few studies have measured $\mathrm{NH}_{3}$ emissions from pastures in the tropics and subtropics and none has compared emissions to inventory estimates. The objectives of this study were to (1) measure $\mathrm{NH}_{3}$ emissions from dairy pastures in tropical and subtropical regions; (2) calculate $\mathrm{NH}_{3}$ emissions factors (EF) for each campaign; and (3) compare measured $\mathrm{EF}$ with those based on the 2006 Intergovernmental Panel on Climate Change (IPCC) Tier 1, 2019 Refinement to the 2006 IPCC Tier 1, and the European Monitoring and Evaluation Programme/European Environmental Agency (EMPE/EEA) Tier 2 inventory estimates. Pasture $\mathrm{NH}_{3}$ emissions were measured on 3 dairy farms in Costa Rica. On each dairy, $\mathrm{NH}_{3}$ emissions were measured twice during the wet season and once during the dry season using a micrometeorological integrated horizontal-flux mass-balance method. Emissions were measured from excreta (dung and urine) deposited by grazing cattle and the subsequent application of organic (slurry) or synthetic fertilizer (ammonium nitrate or urea). Measured EF for all campaigns [from grazing cattle excreta and any subsequent slurry or fertilizer application; $4.9 \pm 0.9 \%$ of applied nitrogen (mean \pm

Received October 31, 2019.

Accepted March 13, 2020.

*Corresponding author: arndt.claudia.ca@gmail.com
SE)] were similar to those of the EMEP/EEA Tier 2 approach $(6.1 \pm 0.9 \%$; mean $\pm \mathrm{SE})$ and 4 times lower than 2006 IPCC and 2019 Refinement to 2006 IPCC Tier 1 default estimates $(17.7 \pm 1.4$ and $18.2 \pm 0.9 \%$, respectively; mean $\pm \mathrm{SE}$ ). Measured EF for excreta deposited on pasture and excreta both deposited on pasture and slurry application $[3.9 \pm 2.1$ and $4.2 \pm$ $2.1 \%$ (mean $\pm 95 \% \mathrm{CI}$ ), respectively] were 5 times lower than default EF assumed by 2006 IPCC and 2019 Refinement to 2006 IPCC methodology (both 20 and $21 \%$, respectively), whereas EMEP/EAA estimates were similar [6.0 and $4.6 \pm 0.3 \%$ (mean $\pm 95 \% \mathrm{CI})$, respectively]. This suggests an overestimation of EF from excreta deposited on pasture and slurry applications in tropical and subtropical regions by IPCC methodologies. Furthermore, rainfall, which is not included as a parameter in the current EMEP/EEA Tier 2 methodology, appeared to reduce $\mathrm{NH}_{3}$ emissions, suggesting that accounting for this in the inventory methodologies could improve inventory estimates.

Key words: $\mathrm{NH}_{3}$ emission, dairy, pasture, tropical

\section{INTRODUCTION}

Ammonia $\left(\mathrm{NH}_{3}\right)$ emissions are an environmental concern, both globally and locally. Globally, $\mathrm{NH}_{3}$ emissions are an indirect source of nitrous oxide $\left(\mathrm{N}_{2} \mathrm{O}\right)$ emissions, which contribute to global warming (IPCC, 2006b). Locally, $\mathrm{NH}_{3}$ emissions cause eutrophication, soil acidification, loss of biodiversity, and, in combination with other atmospheric pollutants, the formation of fine particulate matter, which has damaging effects on human health (Giannadaki et al., 2018). In addition, $\mathrm{NH}_{3}$ emissions are an economic concern because the loss of 
agronomic nitrogen increases the amount of commercial fertilizer needed to optimize crop and pasture yields (UNECE, 2015).

Agriculture is the largest source of $\mathrm{NH}_{3}$ emissions worldwide, with emissions from livestock manure being a major contributor (Behera et al., 2013). In Central and South America, direct soil emissions and emissions from excreta deposited on pastures were estimated to have contributed $6 \%$ of global anthropogenic $\mathrm{NH}_{3}$ emissions in 2012 (EDGAR; http://edgar.jrc.ec .europa.eu/).

Due to the growing demand for livestock products, global meat and dairy production is predicted to increase by 15 and $22 \%$, respectively, by 2027 , compared with the 2015-2017 period (OECD-FAO, 2018). In Latin America and the Caribbean (LAC), this production might increase at an even higher rate. In recent years the livestock sector in LAC had an annual growth rate of $3.5 \%$, which was $67 \%$ greater than the global annual growth rate (2.1\%; OECD-FAO, 2018).

A related issue has emerged because, throughout Central and South America, livestock are produced in pasture-based systems, one of the main drivers of deforestation, with deforestation being a leading cause of rising greenhouse gas levels in the atmosphere (Curtis et al., 2018). To reduce the rate of deforestation and promote reforestation, it is proposed that livestock production be increased through intensification of existing pasture-based systems (Cohn et al., 2014), as has been done in Costa Rica (MAG, 2019). Intensification of pasture-based systems in the tropics, however, would result in increased fertilizer applications and stocking rates. These, in turn, would increase the amount of $\mathrm{N}$ deposited on pastures through excreta from grazing cattle as well as fertilizer and manure applications (Rudel et al., 2015) and thus, increase the risk of $\mathrm{NH}_{3}$ volatilization (Børsting et al., 2003; Smits et al., 2003).

Only a few field studies in Australia (Catchpoole et al., 1983; Harper et al., 1983; Prasertsak et al., 2001; Lam et al., 2018) and none in LAC have measured $\mathrm{NH}_{3}$ emissions from tropical and subtropical pastures using noninvasive micrometeorological techniques. Therefore, more measurements of $\mathrm{NH}_{3}$ emissions from tropical and subtropical pastures are needed to validate inventory estimates.

Currently, inventory estimates for $\mathrm{NH}_{3}$ emissions of excreta (urine and dung) deposited by grazing cattle, as well as for fertilizer and manure applications from pastures in LAC, are made using 2006 Intergovernmental Panel on Climate Change (IPCC) Tier 1 default emissions factors (EF; the \% of applied $\mathrm{N}$ volatilized as $\mathrm{NH}_{3}-\mathrm{N}$; IPCC, 2006b). We are concerned, however, that these 2006 IPCC Tier 1 EF may lack accuracy and precision. Specifically, they do not distinguish between different types of organic or synthetic fertilizers or environmental and soil factors, although it has been long established that these factors can have a large impact on $\mathrm{NH}_{3}$ volatilization from pastures (Núñez et al., 2007). In 2016, Tier $2 \mathrm{EF}$ for $\mathrm{NH}_{3}$ emissions were developed by the European Monitoring and Evaluation Programme (EMEP) and European Environmental Agency (EEA; EMEP/EEA, 2016a,b); in 2019, a refinement to the 2006 IPCC EF was completed (IPCC, 2019). Both the EMEP/EEA Tier $2 \mathrm{EF}$ and the 2019 Refinement to the 2006 IPCC Tier $1 \mathrm{EF}$ account for $\mathrm{NH}_{3}$ emissions from different types of synthetic fertilizers. In addition, the EMEP/EEA Tier 2 EF differentiate between different manure management practices (EMEP/EEA, 2016a) and include the effect of climate and soil pH (EMEP/ EEA, 2016b).

Given the limitations related to such estimations, the objectives of this study were to (1) measure $\mathrm{NH}_{3}$ emissions from dairy pastures in the tropics and subtropics; (2) calculate $\mathrm{NH}_{3} \mathrm{EF}$ for each measurement campaign; and (3) compare measured EF with those provided by the 2006 IPCC Tier 1, 2019 Refinement to 2016 IPCC Tier 1, and EMEP/EEA Tier 2 methodologies.

\section{MATERIALS AND METHODS}

Between January 2018 and April 2019, pasture $\mathrm{NH}_{3}$ emissions measurements were conducted on 3 commercial dairy farms in the Cartago province of Costa Rica, the country's second largest milk producing province (INEC, 2015). On each dairy farm, $\mathrm{NH}_{3}$ measurements took place twice during the wet season and once during the dry season. Measurements were conducted from pastures that were managed under rotational grazing. As the time between grazing and subsequent slurry or synthetic fertilizer applications (urea or ammonium nitrate) was too short to distinguish between the 2 emission sources, $\mathrm{NH}_{3}$ emissions from animal excreta and subsequent fertilizer applications were accounted for together. A combined $\mathrm{EF}$ across all $\mathrm{N}$ sources was therefore derived for each measurement campaign. Measured EF were compared with EF estimates based on 2006 IPCC Tier 1, 2019 Refinement to the 2006 IPCC Tier 1, and EMEP/EEA Tier 2 methodologies. Details of each measurement campaign, including soil and environmental factors, are presented in Table 1.

\section{Study Sites}

One dairy was the commercial dairy farm of the Tropical Agricultural Research and Higher Education Center (CATIE), located $3 \mathrm{~km}$ south east of Turrialba 
Arndt et al.: MEASURED AMMONIA EMISSIONS AND INVENTORY ESTIMATES

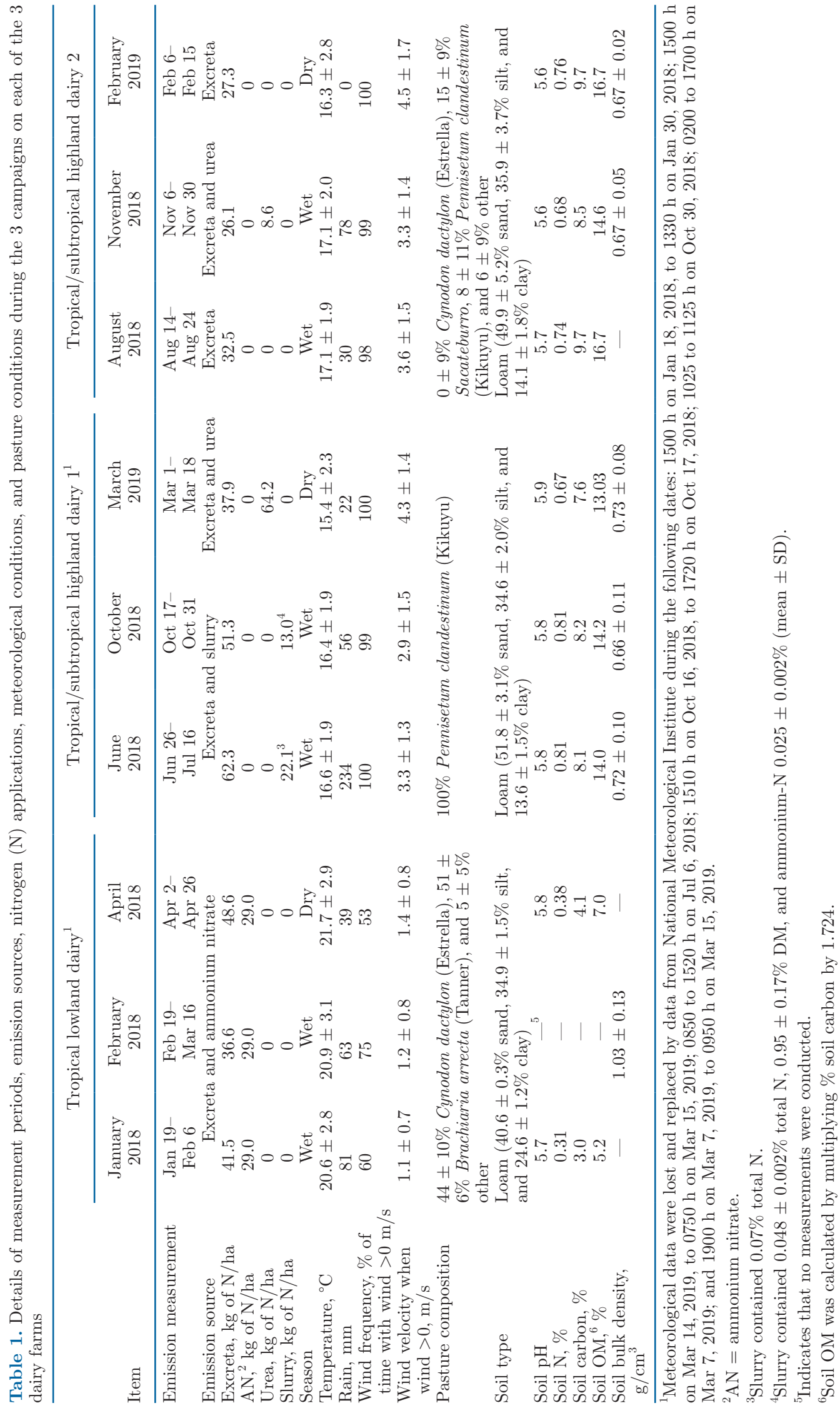


in a tropical rainforest climate (Af on the KöppenGeiger climate classification) at $638 \mathrm{~m}$ above sea level (hereafter, the tropical lowland dairy). The other 2 dairies were located $11 \mathrm{~km}$ east of the city of Cartago in a summer tropical monsoon climate and dry winter subtropical highland climate (Am and $\mathrm{Cwb}$ on the Köppen-Geiger climate classification, respectively) at 1,714 and $1,603 \mathrm{~m}$ above sea level (hereafter, tropical/subtropical highland dairies 1 and 2, respectively). On all dairy farms, lactating cows were grazed under a rotational regimen and supplemented with additional feed (forage and nonforage feeds) in the livestock housing twice a day, before milking. On the tropical lowland dairy and the tropical/subtropical highland dairy 1 cows returned to grazing after p.m. milking during each measurement campaign. On tropical/subtropical highland dairy 2, cows only returned to grazing after p.m. milking when pasture availability was high during the wet season measurement campaigns and stayed indoors overnight during the dry season campaign.

On the tropical lowland dairy, measurements were conducted on pastures with $88 \pm 4$ lactating dualpurpose cattle (mean $\pm \mathrm{SD}$ ). During the measurement campaigns (January 2018, February 2018, and April 2018 ), cows grazed on 0.52 ha of pasture [one half of the pasture after p.m. milking ( 0.26 ha) and the other half after a.m. milking (0.26 ha)] for $16.4 \pm 1.0 \mathrm{~h}$ (mean \pm $\mathrm{SD})$; average milk production was $22.6 \pm 1.6 \mathrm{~kg} / \mathrm{cow}$ per day (mean $\pm \mathrm{SD}$ ), and average DMI was $19.7 \pm 0.7$ $\mathrm{kg} /$ cow per day $[10.4 \pm 0.6 \mathrm{~kg}$ of forage and nonforage feed $\mathrm{DM} /$ cow per day (concentrate feeds and cut forages) and $4.4 \pm 2.9 \mathrm{~kg}$ of pasture/cow per day (mean $\pm \mathrm{SD})]$. On the tropical/subtropical highland dairy 1, measurements were conducted on $94 \pm 7$ lactating Holstein cows (mean $\pm \mathrm{SD}$ ). During the measurement campaigns (June 2018, October 2018, and March 2019), cows were grazed on $0.17 \pm 0.02$ ha (mean $\pm \mathrm{SD}$ ) for $9.2 \pm 0.3 \mathrm{~h}$, average milk production was $31.6 \pm 1.0 \mathrm{~kg} /$ cow per day (mean \pm SD), and average DMI was $24.2 \pm$ $0.2 \mathrm{~kg} /$ cow per day $[19.8 \pm 2.7 \mathrm{~kg}$ of forage and nonforage feed DM/cow per day and $4.4 \pm 2.9 \mathrm{~kg}$ of pasture/ cow per day (mean $\pm \mathrm{SD}$ )]. On tropical/subtropical highland dairy 2, measurements were conducted on pastures with $127 \pm 11$ lactating Brown Swiss cows (mean \pm SD) during all 3 measurement campaigns (August 2018, November 2018, and February 2019). In addition, measurements were conducted on 23 dry cows that grazed the same pasture $2 \mathrm{~d}$ after the lactating cows during the August 2018 measurement campaign. During the 3 measurement campaigns, lactating cows were grazed on $0.44 \pm 0.02$ ha of pasture for $8.0 \pm 0.3$ $\mathrm{h}($ mean $\pm \mathrm{SD})$. Average milk production was $21.3 \pm$ $1.0 \mathrm{~kg} /$ cow per day (mean $\pm \mathrm{SD}$ ), and average DMI was $21.2 \pm 0.7 \mathrm{~kg} /$ cow per day [13.8 $\pm 1.6 \mathrm{~kg}$ of forage and nonforage feed DM/cow per day and $7.4 \pm 1.2 \mathrm{~kg}$ of pasture/cow per day (mean $\pm \mathrm{SD}$ )].

\section{Measurements of Ammonia Emissions}

Pasture $\mathrm{NH}_{3}$ measurements consisted of baseline measurements before grazing (1-4 d) and emission measurements during and after grazing, including emission measurements from any subsequent postgrazing application of slurry or synthetic fertilizer (9-29 d). Ammonia emissions were measured using the micrometeorological integrated horizontal-flux method (Denmead et al., 1977) and passive flux samplers (PFS; Leuning et al., 1985). For each measurement campaign, 5 PFS coated in a $3 \%$ solution of oxalic acid in methanol were deployed on a downwind vertical mast $(4 \mathrm{~m})$ at approximate heights of 4.0, 3.0, 2.0, 1.0, and $0.5 \mathrm{~m}$ (exact heights recorded on each occasion) in the pasture from which emission measurements were to be made. At the same time, 3 PFS were deployed on an upwind mast in an untreated neighboring pasture at approximate heights of 4.0, 2.0, and $0.5 \mathrm{~m}$ to measure the background flux. Closed PFS were deployed on the upwind mast at heights of 1.0 and $3.0 \mathrm{~m}$ and used as blanks. The PFS were deployed for periods between 8 and 96 $\mathrm{h}$, depending on expected $\mathrm{NH}_{3}$ emissions. Following exposure, the PFS were eluted with $40 \mathrm{~mL}$ of deionized water and the extracts were stored at $<4^{\circ} \mathrm{C}$ until analyzed for ammonium (Misselbrook et al., 2005b).

During each measurement campaign, temperature, rainfall, and wind direction and velocity were recorded every $5 \mathrm{~min}$ by a Davis Instruments Vantage Pro II meteorological station (Hayward, CA) within $50 \mathrm{~m}$ of the treated pasture. When meteorological data were lost, they were replaced by hourly data from a weather station of the National Meteorological Institute (IMN, San José, Costa Rica) within $5 \mathrm{~km}$ of each pasture (Table 1).

The net horizontal flux of pasture $\mathrm{NH}_{3}-\mathrm{N}$ emissions was calculated in 2 steps according to Leuning et al. (1985). First, the mean horizontal flux, $\overline{u c}$ (kg of $\mathrm{N} \cdot \mathrm{m}^{-2} \cdot \mathrm{s}^{-1}$ ) at each height for each sampling period was calculated as follows:

$$
\overline{u c}=\frac{M}{A t},
$$

where $M$ is the mass of $\mathrm{NH}_{3}-\mathrm{N}$ collected $(\mathrm{mg})$ in the sampler during the sampling period, $t(\mathrm{~s})$, and $A$ is the effective cross-sectional area of the sampler $\left(\mathrm{m}^{2}\right)$ as determined in wind tunnel calibrations. Second, the net 
horizontal flux of $\mathrm{NH}_{3}-\mathrm{N}$ from the treated area (F, $\mu \mathrm{g}$ of $\mathrm{N} \cdot \mathrm{m}^{-2} \cdot \mathrm{s}^{-1}$ ) was obtained by subtracting the integrated horizontal flux of the upwind mast (uw) from that of the downwind mast $(\mathrm{dw})$ :

$$
\mathrm{F}=\frac{1}{x}\left[\int_{0}^{z}(\overline{u c})_{\mathrm{dw}} \mathrm{d} z-\int_{o}^{z}(\overline{u c})_{\mathrm{uw}} \mathrm{d} z\right],
$$

where $x$ represents the mean fetch length, based on the geometry of the pasture, and $z(\mathrm{~m})$ the height of the uppermost sampler.

Experimental pastures were chosen to ensure flat uniform surfaces with few nearby trees to avoid wind disturbance. For periods when windspeed was $0 \mathrm{~m} / \mathrm{s}$, a fetch length of $0 \mathrm{~m}$ was assigned. The cumulative emission over the entire measurement campaign (from grazing cattle excreta and any subsequent slurry or fertilizer application) was derived by summing the net flux determined for each sampling period. Emission fluxes over time for each campaign are reported in Supplemental Figures S1 to S9 (https://doi.org/10 $.3168 /$ jds.2019-17825).

\section{Estimation of Ammonia Emissions}

Ammonia emissions were estimated using 2006 IPCC Tier 1 (IPCC, 2006b), 2019 Refinement to 2006 IPCC Tier 1 (IPCC, 2019), and EMEP/EEA Tier 2 methodology (EMEP/EEA, 2016a,b). For this, it was necessary to estimate the amount of $\mathrm{N}$ deposited by grazing animals and applied in the form of slurry or fertilizer on the pasture. Estimates of $\mathrm{N}$ deposited on the pasture were based on estimated daily $\mathrm{N}$ excretion per cow, number of grazing cows, and the time spent grazing per day. Fertilizer and slurry $\mathrm{N}$ applications rates were estimated based on the amount of slurry or synthetic fertilizer applied and its $\mathrm{N}$ content.

Daily $\mathrm{N}$ deposited per cow was calculated as the difference between $\mathrm{N}$ intake and $\mathrm{N}$ output in milk. Nitrogen intake was estimated based on a calculation of the feed DMI needed to meet the energy requirements of the dairy cows following 2006 IPCC methodology (IPCC, 2006a) and the $\mathrm{N}$ content of the feed consumed. Net energy requirements for maintenance, activity, lactation, and pregnancy used farm-specific data on cow live weight (measured using a scale for the tropical lowland dairy and a body tape for the tropical/subtropical highland dairies), the 0.17 coefficient for activity, milk yield and composition (recorded on farm), and assumed that $80 \%$ of lactating animals in the herd were pregnant (IPCC, 2006a). We assumed no net change in live weight by the cows, and hence no net energy requirement for gain or loss. The DM, gross energy, and $\mathrm{N}$ intake from feed provided in the livestock housing was calculated based on the amount of feed consumed. The amount of total feed consumed was estimated assuming a diet energy digestibility (\% digestible energy) of $65 \%$ for feeds supplemented in the animal housing and for the pasture (based on 55-75\% of digestible energy for good pastures, good preserved forages, and grainsupplemented forage-based diets) and a diet energy density of $18.45 \mathrm{MJ} / \mathrm{kg}$ of DM (IPCC, 2006a).

Composition of feed provided in the livestock housing and grazed pasture were determined from samples taken for each measurement campaign. At a.m. and p.m. milkings during the first pasture measurement, feed samples were taken, and the amount of feed provided was recorded. Quadrat $(50 \times 50 \mathrm{~cm})$ samples were taken from the measured pasture before the cows entered for grazing, and pasture species composition was determined by visual assessment. Feed and pasture samples were stored at $-20^{\circ} \mathrm{C}$ until oven-dried at $55^{\circ} \mathrm{C}$ to a constant weight. Dried samples were ground to pass through the 2-mm screen of a Wiley mill (Arthur H. Thomas Co., Philadelphia, PA) and analyzed for total N.

The form of fertilizer $\mathrm{N}$ and amount applied (if appropriate) to the pasture were recorded for each farm. Slurry was applied at the tropical/subtropical highland dairy 1 using a cannon slurry spreader at low pressure during both wet season measurement campaigns $1 \mathrm{~d}$ after the cows grazed the pasture (August 2018 and October 2018). Slurry consisted of dung and urine excreted during feed supplementation and milking and wash water from the livestock housing and milking parlor. Slurry was sampled during the first campaign after the slurry tank had been thoroughly mixed by pumping and during the second campaign by positioning 5 buckets in random locations on the field during slurry application. The sampled slurry was stored at $4^{\circ} \mathrm{C}$ until analyzed for total $\mathrm{N}$ and DM. In addition, the sampled slurry from the October 2018 campaign was analyzed for total ammonium $\mathrm{N}$ (TAN) and $\mathrm{pH}$. The volume of slurry application and slurry $\mathrm{N}$ content was then used to estimate the slurry $\mathrm{N}$ application rate. As cattle spent only about $6 \mathrm{~h} / \mathrm{d}$ in livestock housing (mainly during milking), and water was used to clean the parlors, the total $\mathrm{N}$, TAN, and DM contents of the slurry were very diluted $(<0.05 \%,<0.03 \%$, and $<1.0 \%$, respectively; Table 1). Indeed, slurry composition was similar to that of dirty water (AHDB, 2017).

Ammonia emission predictions were made based on 2006 IPCC Tier 1, 2019 Refinement to 2006 IPCC Tier 1, and EMEP/EEA Tier 2 methodology and the 
estimated amounts and forms of $\mathrm{N}$ deposited on each pasture during each measurement campaign. The 2006 IPCC Tier 1 default EF estimates that $10 \%$ (uncertainty range 3 to $30 \%$ ) of $\mathrm{N}$ from applied synthetic fertilizer and $20 \%$ (uncertainty range 5.0 to $50 \%$ ) of $\mathrm{N}$ from all organic fertilizer (including slurry applications and animal excreta deposited on a pasture) are volatilized as $\mathrm{NH}_{3}$-N. In contrast, the 2019 Refinement to 2006 IPCC Tier 1 default accounts for differences between fertilizer types, and estimates that 15 (uncertainty range 3.0 to $43 \%$ ) and $5 \%$ (uncertainty range 0 to $20 \%$ ) of $\mathrm{N}$ from urea and ammonium-nitrate, respectively, are volatilized as $\mathrm{NH}_{3}-\mathrm{N}$. For organic fertilizer (slurry) and animal excreta deposited on pasture by grazing cattle, the default $\mathrm{EF}$ is $21 \%$ (uncertainty range 0 to $31 \%$ ). The EMEP/EEA Tier 2 methodology estimates that under warm climate conditions with normal soil $\mathrm{pH}$ $(\mathrm{pH} \leq 7) 19.8$ and $2.0 \%$ of $\mathrm{N}$ from urea and ammonium nitrate, respectively, are volatized as $\mathrm{NH}_{3}-\mathrm{N}$. The Tier $2 \mathrm{EF}$ for grazing cattle and slurry application are 10 and $55 \%$, respectively, of TAN excreted or applied, with TAN assumed to be $60 \%$ of the total $\mathrm{N}$ content, which equals an EF of 6 and $33 \%$ for applied excreta and slurry, respectively.

\section{Soil Sampling}

Soil samples to $20 \mathrm{~cm}$ depth were taken during each measurement campaign on each dairy farm, except for the tropical lowland dairy during the second campaign (February 2018), and analyzed for pH, N, and C. Soil bulk density was determined using the cylinder method (Blake and Hartge, 1986), with samples taken at 5 locations for each pasture to $20 \mathrm{~cm}$ depth.

\section{Laboratory Analysis}

Soil $\mathrm{pH}$ was analyzed by extraction of water in a ratio of 1:2.5 (Díaz and Hunter, 1978). Slurry pH was measured directly using a $\mathrm{pH}$ meter (Orion Research with glass electrode; Orion Research Inc., Cambridge, MA). Soil minerals were determined by modified Olson solution at $\mathrm{pH} 8.5$ in a ratio of soil and water of 2.5:25. Analytical DM content was determined by drying samples at $105^{\circ} \mathrm{C}$ for $3 \mathrm{~h}$ (Shreve et al., 2006). Slurry $\mathrm{DM}$ was determined by oven drying at $105^{\circ} \mathrm{C}$ for 24 h. Nitrogen content of dietary supplements, pasture, soil, and slurry was determined using a ThermoFinnigan analyzer (Flash EA 1112 Elemental Analyzer Operation Manual, ThermoFinnigan Italia, Milan, Italy). The ammonium- $\mathrm{N}$ content was determined using the Kjeldahl method without digestion (AOAC, 1980). Ammonium concentration of the water extracts from the PFS was analyzed by colorimetric method according to Baethgen and Alley (1989).

\section{Statistical Analysis}

The statistical analysis of measured and estimated EF was carried out using R (version 3.5.1; https://www .R-project.org/) with the nlme package and the following mixed-effects model:

$$
\mathrm{Y}_{\mathrm{ij}}=\mu+\mathrm{m}_{\mathrm{i}}+\mathrm{d}_{\mathrm{j}}+\mathrm{e}_{\mathrm{ij}},
$$

where $\mathrm{Y}_{\mathrm{ij}}$ is the dependent variable $(\mathrm{EF}) ; \mu$ is the overall mean; $\mathrm{m}_{\mathrm{i}}$ is the fixed effect of method (measurement, IPCC, or EMEP); $d_{j}$ is the random residual effect of dairy farm ( $\mathrm{j}=1$ to 3 ); and $\mathrm{e}_{\mathrm{ij}}$ is the random residual, assumed to be normally and independently distributed.

\section{RESULTS AND DISCUSSION}

\section{Measured Ammonia Emissions}

Measured $\mathrm{NH}_{3}$ emissions were lowest for excreta and ammonium nitrate during the wet season for the tropical lowland dairy compared with the tropical/subtropical highland dairies (Table 2). Low $\mathrm{NH}_{3}$ emissions were expected, as the Tier $2 \mathrm{EF}$ for ammonium nitrate fertilizer is only $2 \%$ for warm climates and normal soil $\mathrm{pH}$ (EMEP/EEA, 2016b). However, the measured EF for the January 2018 campaign was close to $0 \%$. This might have been the result of $\mathrm{N}$ runoff due to saturated soils caused by heavy rain before the start of the $\mathrm{NH}_{3}$ measurements (202 $\mathrm{mm}$ of rain during the $3 \mathrm{~d}$ of baseline measurements and $15 \mathrm{~mm}$ of rainfall during the first $48 \mathrm{~h}$ of emission measurements). In addition, $6 \mathrm{~mm}$ of rain fell within $24 \mathrm{~h}$ after the application of ammonium nitrate, potentially leading to $\mathrm{N}$ runoff or $\mathrm{N}$ being moved below the soil surface, resulting in low $\mathrm{NH}_{3}$ emissions. Similarly, during the February 2018 campaign, $15 \mathrm{~mm}$ of rain fell within $24 \mathrm{~h}$ after cows grazed the pasture and $5 \mathrm{~mm}$ of rain fell within $24 \mathrm{~h}$ of ammonium nitrate application. Rainfall has previously been shown to decrease total $\mathrm{NH}_{3}$ emissions from applied fertilizer $\mathrm{N}$ and cattle slurry, with the amount and timing being of importance (Misselbrook et al., 2004, 2005b; Chambers and Dampney, 2009). Emissions were greater during the dry season (April 2018 campaign) than during the wet season campaigns (January and February 2018), as might be expected with the lower incidence of rainfall and higher temperatures.

At tropical/subtropical highland dairy 2, excreta and slurry emissions were smaller during the June 2018 campaign than during the October 2018 campaign 
Table 2. Measured accumulated ammonia nitrogen $\left(\mathrm{NH}_{3}-\mathrm{N}\right)$ emissions and emission factors from excreta (dung and urine) deposited by grazing cattle and organic or synthetic fertilizer (slurry or synthetic fertilizer) when applied on pastures of 3 Costa Rican dairy farm

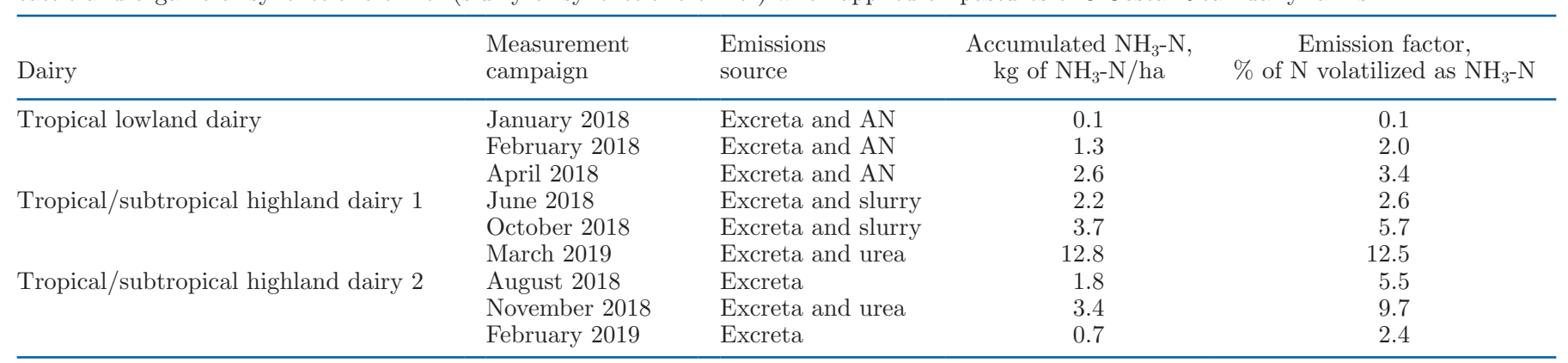

${ }^{1} \mathrm{AN}=$ ammonium nitrate.

(combined $\mathrm{EF}$ of $2.6 \%$ vs. $5.7 \%$ ). The difference in $\mathrm{NH}_{3}$ emissions cannot be explained by the higher rainfall during the June 2018 compared with the October 2018 campaign (234 vs. $56 \mathrm{~mm}$ ) because $152 \mathrm{~mm}$ of the rain during June fell within the last $73 \mathrm{~h}$ of the measurements, nor by other factors such as temperature, as they were similar (Table 1). Measured EF for excreta and urea emissions during the dry season (March 2019 campaign) at tropical/subtropical highland dairy 1 were greater, although not markedly so, than for excreta and urea emissions from subtropical/tropical highland dairy 2 during the wet season. The combined EF, accounting for both excreta and urea fertilizer application (9.7 and $12.5 \%$ for dry and wet season, respectively) were within the range of EF reported by other authors for urea applications of subtropical pastures. Lam et al. (2018) reported an EF of $15.8 \%$ during the dry season and Harper et al. (1983) reported EF of $9,12,42$, and $13 \%$ during spring, summer, autumn, and winter, respectively. Although for our study, we cannot derive independent $\mathrm{EF}$ for the excreta and urea fertilizer, EF for urea have been shown to increase with increasing application rate (Rochette et al., 2013), and this may partly explain the observed lower EF on tropical/subtropical highland dairy 2 compared with dairy 1 (9.7 vs. $12.5 \%$ ) as the urea $\mathrm{N}$ application rate on the tropical/subtropical highland dairy 2 was lower than on the tropical/subtropical highland dairy 1 (8.6 vs. 64.2 $\mathrm{kg}$ of $\mathrm{N} / \mathrm{ha}$ ).

For excreta only, the EF on the tropical/subtropical highland dairy 2 was greater during the wet (August 2018 campaign with $30 \mathrm{~mm}$ of rain) than the dry season (February 2018 campaign with $0 \mathrm{~mm}$ of rain; 5.5 vs. $2.4 \%$, respectively). This is contrary to what was expected because infiltration of urine into the soil is affected by the antecedent soil water content, being greater when the soil is moist than when dry (Doak, 1952). Additionally, mean temperature was only slightly lower during the February 2019 compared with the August 2018 campaign ( 16.3 vs. $17.1^{\circ} \mathrm{C}$ ). However, results are similar to emissions reported by Petersen et al. (1998), who found that $\mathrm{NH}_{3}$ volatilization from urine ranges from 2 to $52 \%$ of urinary $\mathrm{N}$ and that $\mathrm{NH}_{3}$ volatilization of dung in pastures is negligible.

\section{Measured and Estimated Emission Factors}

The $\mathrm{EF}$ derived from $\mathrm{NH}_{3}$ measurements for all campaigns (from grazing cattle excreta and any subsequent slurry or fertilizer application; mean $\pm \mathrm{SE}=4.9 \pm 0.9 \%$ ) were similar to 2006 IPCC Tier 1 minimum estimates (mean $\pm \mathrm{SE}=3.9 \pm 0.9 \% ; P=0.63$ ) and those derived using the EMEP/EEA Tier 2 approach (mean \pm SE $=6.1 \pm 0.9 \% ; P=0.98 ;$ Figure 1 ). They were 4 times lower than 2006 IPCC default Tier 1 estimates (mean $\pm \mathrm{SE}=17.7 \pm 1.4 \% ; P<0.001)$ and 2019 Refinement to 2006 IPCC default Tier 1 estimates (mean $\pm \mathrm{SE}=$ $18.2 \pm 0.9 \% ; P<0.001)$. The EF estimated by EMEP/ EEA Tier 2 methodology were closest to EF derived from all measurement campaigns. This is most likely because the EMEP/EEA Tier 2 methodology approach estimates lower EF for excreta deposited by grazing cattle on pastures. Measured EF for excreta deposited by grazing cattle (mean $\pm 95 \% \mathrm{CI}=3.9 \pm 2.1 \%$; Table 2 ) were 5 times lower than default EF assumed by 2006 IPCC and 2019 Refinement to 2006 IPCC methodology (20 and 21\%, respectively), whereas the EF assumed by EMEP/EAA methodology (6.0\%) was similar. These results, in combination with measured $\mathrm{EF}$ for both excreta deposited by grazing cattle and applied slurry (mean $\pm 95 \% \mathrm{CI}=4.2 \pm 2.1 \%$; Table 2 ) suggest that the 2006 IPCC and the 2019 Refinement to 2006 IPCC default Tier $1 \mathrm{EF}$ for cow excreta and slurry (both 20 and $21.0 \%$, respectively) might overestimate emissions for slurry, whereas EMEP/EAA estimates are similar to those measured in this study (mean $\pm 95 \% \mathrm{CI}=4.6 \pm$ $0.3 \%)$. The very low slurry $\mathrm{N}$ and $\mathrm{DM}$ content $(<0.1 \%$ and $<1.0 \%$, respectively) are likely to explain the low 


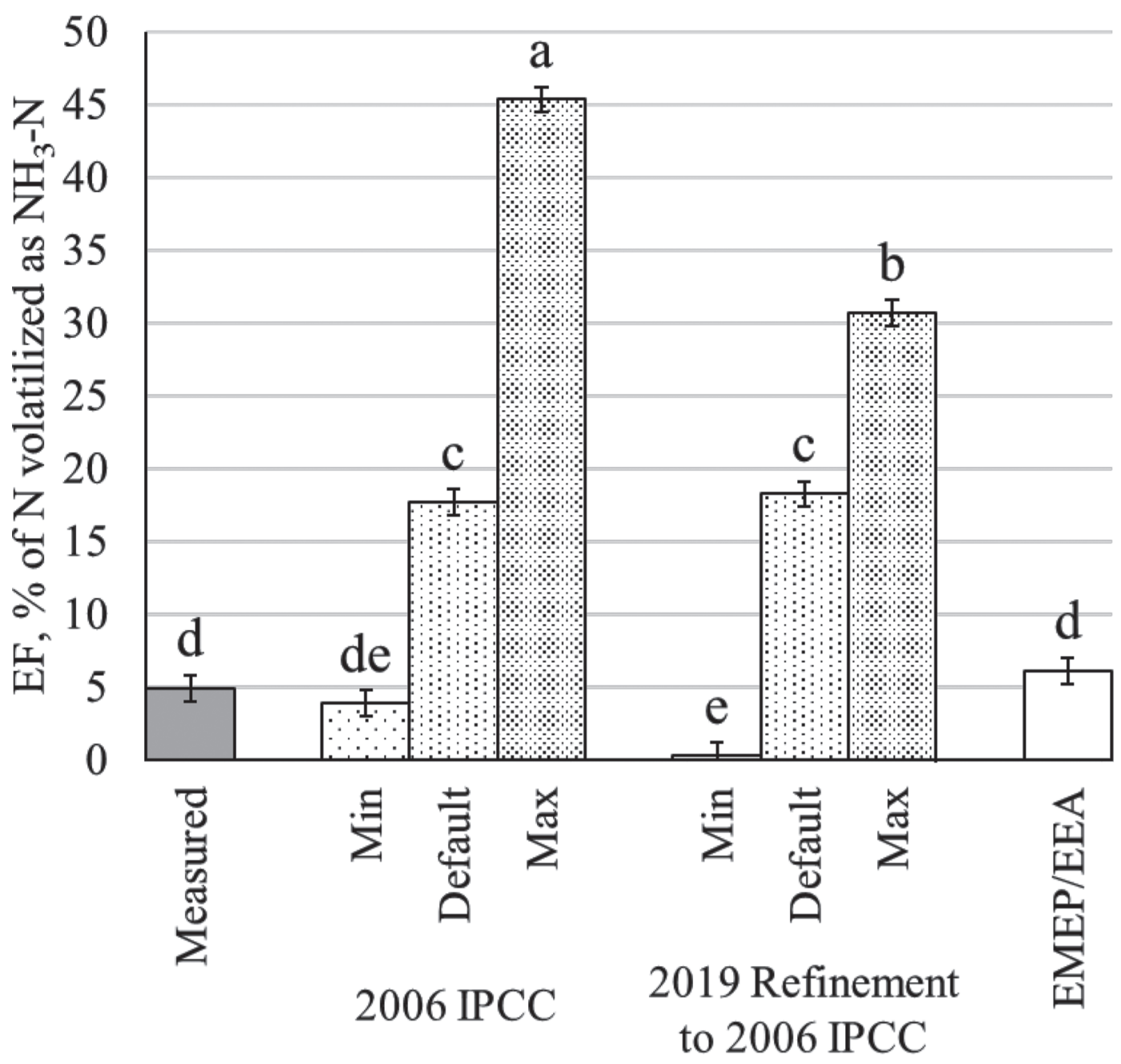

Figure 1. Measured emission factors (EF) compared with those estimated [minimum (Min), default, and maximum (Max)] by 2006 IPCC (IPCC, 2006a,b), 2019 Refinement to the 2006 IPCC (IPCC, 2019), and EMEP/EEA (2016a,b) (all n = 9). Emission factors are presented as least squares means of the percentage of applied nitrogen that is volatilized as ammonia nitrogen $\left(\mathrm{NH}_{3}-\mathrm{N}\right)$. Error bars represent standard errors; least squares means not sharing common letters $(\mathrm{a}-\mathrm{e})$ are significantly different $(P<0.05)$.

$\mathrm{NH}_{3}$ emissions from slurry (Sommer and Olesen, 1991; Misselbrook et al., 2005a). Nevertheless, both the EF for excreta and slurry should undergo further evaluation for the tropics and subtropics.

\section{CONCLUSIONS}

Our results suggest that 2006 IPCC Tier 1 and 2019 Refinement to 2006 IPCC Tier 1 methodology overestimate $\mathrm{NH}_{3}$ emissions from excreta deposited by grazing dairy cattle on pastures in the tropics and subtopics, whereas the EMEP/EEA Tier 2 methodology does not. Further, it suggests that EF for 2006 IPCC and 2019 Refinement to 2016 IPCC methodologies overestimate $\mathrm{EF}$ for applications of the very dilute slurries associated with these dairy systems. To verify the findings of this study, we recommend further $\mathrm{NH}_{3}$ measurements from excreta and slurry in the tropics and subtropics and also recommend revision of the 2006 IPCC and 2019 Refinement to 2016 IPCC Tier 1 EF if needed. Until then, $\mathrm{NH}_{3}$ emissions in the tropics and subtropics seem to be best predicted by EMEP/EEA Tier 2 methodology. In countries with high numbers of grazing livestock, we recommend the use of EMEP/EEA Tier 2 methodology instead of the 2006 IPCC Tier 1 or 2019 Refinement to 2006 IPCC Tier 1 methodology. Rainfall, which is not included as a parameter in the current EMEP/EEA Tier 2 methodology, appeared to influence $\mathrm{NH}_{3}$ emissions from grazed pastures. This is of particular significance for tropical and subtropical systems due to rainfall extremes during wet and dry seasons. Accounting for this in the inventory methodologies (perhaps using a "seasonal" factor) could improve inventory estimates. 


\section{ACKNOWLEDGMENTS}

We thank the UK Global Challenge Research Fund (GCRF, Swindon, UK) for funding project BB/ P023150/1 "Sustainable futures for the Costa Rica dairy sector: Optimising environmental and economic outcomes"). The authors are grateful to the commercial dairy farmers for letting us access their farms and to farm managers and farm workers for helping us during the measurements. We also thank the National Meteorological Institute of Costa Rica for providing us with meteorological data. Further, we extend gratitude to Jean E. Fargo (retired English teacher, New York City, NY) for editorial suggestions. The authors have not stated any conflicts of interest.

\section{REFERENCES}

AHDB. 2017. Nutrient Management Guide (RB209). Section 2. Organic Materials. Agriculture and Horticulture Development Board, Kenilworth, UK.

AOAC. 1980. Official Methods of Analysis. 13th ed. Assoc. Off. Anal. Chem., Washington DC.

Baethgen, W. E., and M. M. Alley. 1989. A manual colorimetric procedure for measuring ammonium nitrogen in soil and plant Kjeldahl digests. Commun. Soil Sci. Plant Anal. 20:961-969. https://doi .org/10.1080/00103628909368129.

Behera, S. N., M. Sharma, V. P. Aneja, and R. Balasubramanian. 2013. Ammonia in the atmosphere: A review on emission sources, atmospheric chemistry and deposition on terrestrial bodies. Environ. Sci. Pollut. Res. Int. 20:8092-8131. https://doi.org/10.1007/ s11356-013-2051-9.

Blake, G. R., and K. H. Hartge. 1986. Bulk density. Pages 374-390 in Methods of Soil Analysis, Part 1-Physical and Mineralogical Methods. 2nd ed. Agronomy Monograph 9. A. Klute, ed. American Society of Agronomy-Soil Science Society of America, Madison, WI.

Børsting, C. F., T. Kristensen, L. Misciattelli, T. Hvelplund, and M. Weisbjerg. 2003. Reducing nitrogen surplus from dairy farms. Effects of feeding and management. Livest. Prod. Sci. 83:165-178. https://doi.org/10.1016/S0301-6226(03)00099-X.

Catchpoole, V., D. Oxenham, and L. Harper. 1983. Transformation and recovery of urea applied to a grass pasture in south-eastern Queensland. Aust. J. Exp. Agric. 23:80-86. https://doi.org/10 $.1071 /$ EA9830080.

Chambers, B. J., and P. Dampney. 2009. Nitrogen efficiency and ammonia emissions from urea-based and ammonium nitrate fertilisers. Proceedings No. 657. Int. Fertil. Soc., Colchester, UK.

Cohn, A. S., A. Mosnier, P. Havlík, H. Valin, M. Herrero, E. Schmid, M. O'Hare, and M. Obersteiner. 2014. Cattle ranching intensification in Brazil can reduce global greenhouse gas emissions by sparing land from deforestation. Proc. Natl. Acad. Sci. USA 111:72367241. https://doi.org/10.1073/pnas.1307163111.

Curtis, P. G., C. M. Slay, N. L. Harris, A. Tyukavina, and M. C. Hansen. 2018. Classifying drivers of global forest loss. Science 361:1108-1111. https://doi.org/10.1126/science.aau3445.

Denmead, O. T., J. R. Simpson, and J. R. Freney. 1977. A direct field measurement of ammonia emission after injection of anhydrous ammonia. Soil Sci. Soc. Am. J. 41:1001-1004. https://doi.org/10 $.2136 /$ sssaj1977.03615995004100050039x.

Díaz, R. R., and A. Hunter. 1978. Metodología de muestreo de suelos, análisis químico de suelos y tejido vegetal e investigación en invernadero. CATIE, Turrialba, Costa Rica.

Doak, B. W. 1952. Some chemical changes in the nitrogenous constituents of urine when voided on pasture. J. Agric. Sci. 42:162-171. https://doi.org/10.1017/S0021859600058767.
EMEP/EEA. 2016a. EMEP/EEA airpollutant emission inventory guidebook 2016 - Update Nov 2016. Chapter 3.B. Manure management. European Monitoring and Evaluation Programme and European Environmental Agency (EMEP/EEA), Copenhagen, Denmark.

EMEP/EEA. 2016b. EMEP/EEA airpollutant emission inventory guidebook 2016 - Update Nov 2016. Chapter 3.D. Crop production of agricultural soils. European Monitoring and Evaluation Programme and European Environmental Agency (EMEP/EEA), Copenhagen, Denmark.

Giannadaki, D., E. Giannakis, A. Pozzer, and J. Lelieveld. 2018. Estimating health and economic benefits of reductions in air pollution from agriculture. Sci. Total Environ. 622-623:1304-1316. https:// doi.org/10.1016/j.scitotenv.2017.12.064.

Harper, L. A., V. R. Catchpoole, and I. Vallis. 1983. Ammonia loss from fertilizer applied to tropical pastures. Pages 195-214 in Gaseous Loss of Nitrogen from Plant-Soil Systems. Developments in Plant and Soil Sciences. Vol 9. J. R. Freney and J. R. Simpso, ed. Springer, Dordrecht, the Netherlands.

INEC. 2015. VI Censo nacional agropecuario resultados generales. San José, Costa Rica. Accessed Oct. 31, 2019. http://www.mag.go.cr/ bibliotecavirtual/U40-10581.pdf.

IPCC. 2006a. Chapter 10: Emissions from livestock and manure management. In IPCC Guidelines for National Greenhouse Gas Inventories Volume 4: Agriculture, forestry and other land use. Intergovernmental Panel on Climate Change, Geneva, Switzerland.

IPCC. 2006b. Chapter 11: $\mathrm{N}_{2} \mathrm{O}$ emissions from managed soils, and $\mathrm{CO}_{2}$ emissions from lime and urea application. Intergovernmental Panel on Climate Change, Geneva, Switzerland.

IPCC. 2019. 2019 Refinement to the 2006 IPCC Guidelines for National Greenhouse Gas Inventories. Chapter 11: $\mathrm{N}_{2} \mathrm{O}$ emissions from managed soils, and $\mathrm{CO}_{2}$ emissions from lime and urea application. Intergovernmental Panel on Climate Change, Geneva, Switzerland.

Lam, S. K., H. Suter, M. Bai, C. Walker, R. Davies, A. R. Mosier, and D. Chen. 2018. Using urease and nitrification inhibitors to decrease ammonia and nitrous oxide emissions and improve productivity in a subtropical pasture. Sci. Total Environ. 644:1531-1535. https://doi.org/10.1016/j.scitotenv.2018.07.092.

Leuning, R., J. R. Freney, O. T. Denmead, and J. R. Simpson. 1985. A sampler for measuring atmospheric ammonia flux. Atmos. Environ. 19:1117-1124. https://doi.org/10.1016/0004-6981(85)90196-9.

MAG. 2019. Costa Rica, en ruta hacia la descarbonización de la ganadería 2013-2018. San José, Costa Rica. Accessed Oct. 31, 2019. http://www.mag.go.cr/bibliotecavirtual/L01-11076.PDF.

Misselbrook, T. H., F. A. Nicholson, and B. J. Chambers. 2005a. Predicting ammonia losses following the application of livestock manure to land. Bioresour. Technol. 96:159-168. https://doi.org/10 .1016/j.biortech.2004.05.004.

Misselbrook, T. H., F. A. Nicholson, B. J. Chambers, and R. A. Johnson. 2005b. Measuring ammonia emissions from land applied manure: An intercomparison of commonly used samplers and techniques. Environ. Pollut. 135:389-397. https://doi.org/10.1016/j .envpol.2004.11.012.

Misselbrook, T. H., M. A. Sutton, and D. Scholefield. 2004. A simple process-based model for estimating ammonia emissions from agricultural land after fertilizer applications. Soil Use Manage. 20:365372. https://doi.org/10.1111/j.1475-2743.2004.tb00385.x.

Núñez, P., R. Demanet, F. Matus, and M. L. Mora. 2007. Grazing management, ammonia and nitrous oxide emissions: A general view. Rev. Cienc. Suelo Nutr. Veg. 7:61-99. https://doi.org/10 .4067/S0718-27912007000300006.

OECD-FAO. 2018. OECD-FAO agricultural outlook 2018-2027. Special focus: Latin America. FAO, Rome. Accessed Oct. 31, 2019. http://www.fao.org/3/ca4076en/ca4076en.pdf.

Petersen, S., S. G. Sommer, O. Aaes, and K. Søegaard. 1998. Ammonia losses from urine and dung of grazing cattle: Effect of $\mathrm{N}$ intake. Atmos. Environ. 32:295-300. https://doi.org/10.1016/S1352 $-2310(97) 00043-5$.

Prasertsak, P., J. R. Freney, O. T. Denmead, P. G. Saffigna, and B. G. Prove. 2001. Significance of gaseous nitrogen loss from a tropical 
dairy pasture fertilised with urea. Aust. J. Exp. Agric. 41:625-632. https://doi.org/10.1071/EA00131.

Rochette, P., D. Angers, M. Chantigny, M. Gasser, D. Macdonald, D. Pelster, and N. Bertrand. 2013. $\mathrm{NH}_{3}$ volatilization, soil $\mathrm{NH}_{4}^{+}$ concentration and soil $\mathrm{pH}$ following subsurface banding of urea at increasing rates. Can. J. Soil Sci. 93:261-268. https://doi.org/10 .4141/cjss2012-095.

Rudel, T. K., B. Paul, D. White, I. Rao, R. van der Hoek, A. Castro, M. Boval, A. Lerner, L. Schneider, and M. Peters. 2015. LivestockPlus: Forages, sustainable intensification, and food security in the tropics. Ambio 44:685-693. https://doi.org/10.1007/s13280 $-015-0676-2$

Shreve, B., N. Thiex, and M. Wolf. 2006. National Forage Testing Association (NFTA) method 2.1.4 - Dry matter by oven drying for 3 hours at $105^{\circ} \mathrm{C}$. NFTA, Omaha, NE. Accessed Oct. 31, 2019. https: //cfa.uaeu.ac.ae/en/doc/aridland/moisture_analysis.pdf.
Smits, M. C. J., G. J. Monteny, and G. van Duinkerken. 2003. Effect of nutrition and management factors on ammonia emission from dairy cow herds: Models and field observations. Livest. Prod. Sci. 84:113-123. https://doi.org/10.1016/j.livprodsci.2003.09.014.

Sommer, S. G., and J. Olesen. 1991. Effects of dry matter content and temperature on ammonia loss from surface-applied cattle slurry J. Environ. Qual. 20:679-683. https://doi.org/10.2134/jeq1991 $.00472425002000030029 x$.

UNECE. 2015. United Nations Economic Commission for Europe. Framework Code for Good Agricultural Practice for Reducing Ammonia Emissions. Accessed Oct. 31, 2019. https://www.unece .org/fileadmin/DAM/env/lrtap/Publications/Ammonia_SR136 _28-4_HR.pdf. 